Research, part of a Special Feature on Nudging Evolution? Critical Exploration of the Potential and Limitations of the Concept of Institutional Fit for the Study and Adaptive Management of Social-Ecological Systems

\title{
Institutional Misfits: Law and Habits in Finnish Wolf Policy
}

\author{
$\underline{\text { Juha Hiedanpää }}{ }^{l}$
}

ABSTRACT. Finland has struggled with formulating and implementing policies regarding the national grey wolf (Canis lupus) population. It seems that after major institutional adjustments undertaken to improve wolf protection, the wolf population has, in fact, decreased. This calls for an explanation. My approach to the question of institutional fit builds upon classical institutional economics and pragmatism. I will apply Charles S. Peirce's conception of habits and his theory of categories and the idea of normative sciences. The case study from southwestern Finland shows that if the institutional designers would address the habits of feeling, mind, and action, including their own, that frame and constitute the problematic situation and potential solutions, the critical conditions of institutional fit would be more tangible and easier to identify and handle. As long as policy adjustments are reactive and compulsive and not built upon a reasonable engagement of whole epistemic community in habit-breaking and habit-taking, policies will most likely fail.

Key Words: grey wolf (Canis lupus); habits; institutional fit; institutions; policy; pragmatism

\section{INTRODUCTION}

Finland has struggled with formulating and implementing policies regarding the national wolf population. The presence of the grey wolf (Canis lupus) is a rather peculiar environmental problem because its hundred-year-long near extinction means that it seems like a foreign invader but is actually native to the area. Finland's accession to the European Union (EU) in 1995 started a new era of large carnivore policy. The wolf became strictly protected by the European Union's Habitats Directive. In addition, after major institutional adjustments undertaken to improve wolf protection, the wolf population has, in fact, decreased (Figure 1). This calls for an explanation.

Fig. 1. The wolf population in Finland (Kojola et al. 2011).

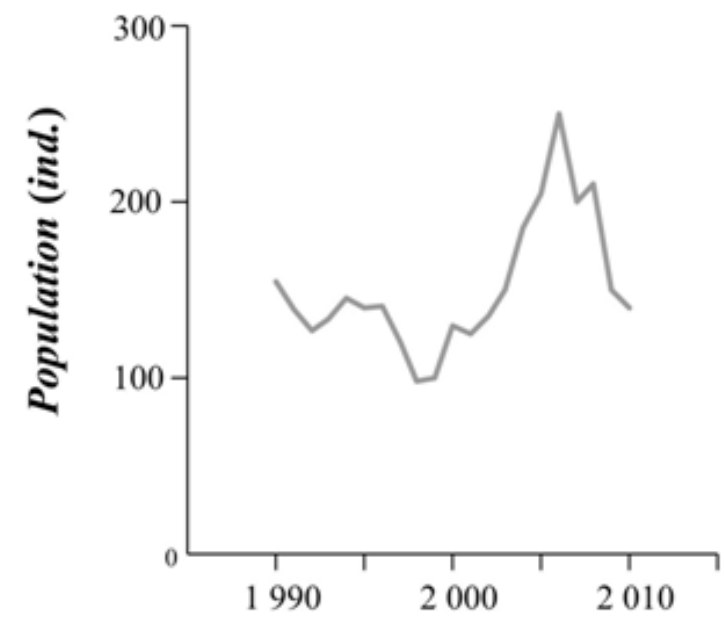

${ }^{1}$ Finnish Game and Fisheries Research Institute
Figure 1 shows that the pre-EU wolf policy was unable to strengthen the viability of the wolf population. The population size dipped in the late 1990s; consequently, the European Commission initiated Infringement Proceedings (2001) to compel Finland to improve large carnivore protection. As part of the wildlife administration's reaction to the infringement procedure, an unprecedented effort to date to involve the public in wolf policy making in Finland took place. Finland prepared the Wolf Management Plan (Management 2005) based on various meetings and public hearings organized across Finland (Bisi and Kurki 2008). The wolf population increased during this period.

The Commission called the case to the European Court of Justice (ECJ) in 2005. The Commission claimed that (1) the conservation status of the wolf in Finland was not favorable; (2) Finland had not honored the principle of strict protection; and (3) Finland had not adequately explored feasible alternatives to wolf predation to reduce livestock losses. Following an investigation into these allegations, the Court rendered its judgment in June 2007. Finland was found to be at fault in one of the charges (2) but not the other two $(1,3)$. The Court ordered the Finnish government to rectify its failure to offer strict protection to wolves. In the two other respects, the Finnish wolf policy was in line with the Habitats Directive (European Court of Justice 2007, Hiedanpää and Bromley 2011).

In 2008, the estimated wolf population in Finland was approximately 200 (compared to 130-140 in 1995). The population spread to and increased in western Finland. However, the population has declined since 2008. Currently, the estimated winter population is approximately 120-135 wolves (winter 2013 estimate). The apparent decline of wolves 
Fig. 2. The Pyhäjärvi area

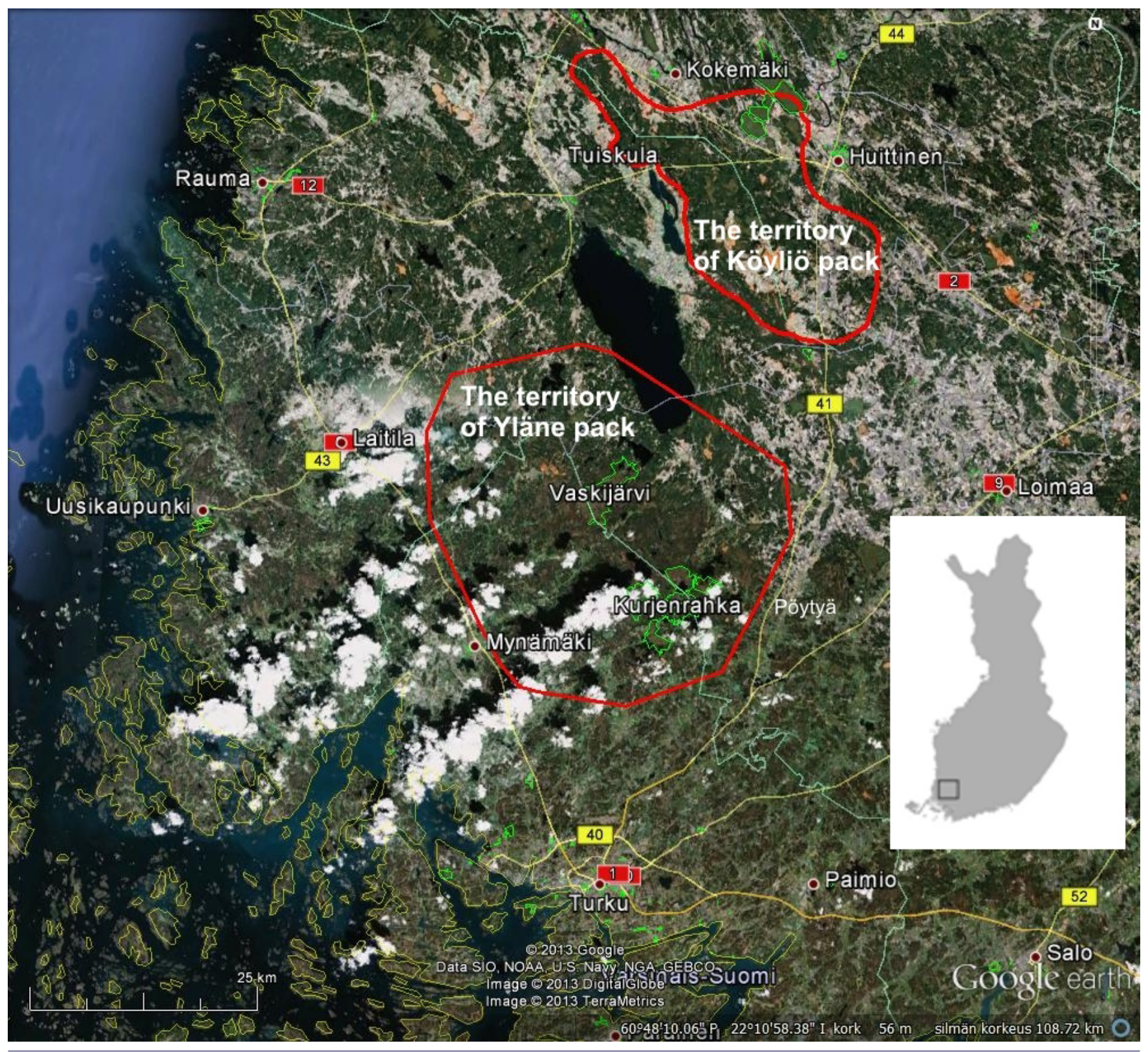

across Finland has only one plausible explanation: illegal killing of the wolves. According to the Finnish Game and Fisheries Research Institute (RKTL), there were no biological reasons for their disappearance; the roe deer and moose populations were sufficiently dense and there were no signs of lethal diseases (Kojola et al. 2011).

I will explain why it is useful to discuss institutional misfit in the context of Finnish wolf policy. The spatial case is that of the Pyhäjärvi area, where the first severe wolf predation of livestock in a hundred years happened in August 2008. Wolves killed or lethally injured 65 sheep in Köyliö on four pastures during July and August. Two communities in particular, Köyliö and Pöytyä, were taken by surprise since both of them have wolf packs of their own, the Köyliö pack in Köyliö and the Yläne pack in Pöytyä (see Figure 2). These relatively small communities (3,500 and 8,500 residents, respectively) are located within $50 \mathrm{~km}$ of three major southern Finnish cities: Tampere, Turku, and Pori. It is a flat area with a relatively broad state-owned wilderness area, Vaskijärvi Strict Nature Reserve $\left(15 \mathrm{~km}^{2}\right)$ and Kurjenrahka National Park, along with 
several large private estates and a multitude of small farms (approximately 70 percent of forest in southwestern Finland is privately owned, and the average size of forest property is approximately 30 hectares).

While drawing on the concept of fit developed by Young (2002, 2008), I will offer a variation on his approach. First, in my treatment, the questions concerning institutional fit and interplay are intertwined: the pre-existing institutional arrangements and local people are part of both the problem and the solution (see Vatn and Vedeld 2012). Second, the strict separation between institutions (as potential solutions) and ecosystems (as potential problems) cannot be made (see Bromley 2012). I will build on a pragmatist view and suggest that institutional fit concerns habits and how they interlock. In particular, fit is about habit-breaking and habit-taking. I follow John Dewey and especially Charles Sanders Peirce in claiming that a richer definition of institutional fit than Young's $(2002,2008)$ is available. My main argument is that the policies that focus only on habit-breaking and ignore habittaking will most likely fail. I will argue that if the institutional designers would address and acknowledge the habits of feeling, action, and mind, including their own, that frame and constitute the problematic situation and potential solutions, the matter of institutional fit would become easier to identify and handle.

\section{THEORETICAL NAVIGATION}

\section{What are institutions?}

According to the most customary definition, institutions are formal or informal rules. Institutions may then be articulated rules enforced with sanctions, incentives, unarticulated traditions, customs, and moral norms. This line of reasoning follows the new institutionalism of, for instance, Douglass C. North (2005) and Oliver Williamson (1996) (on old and new institutionalism, see Rutherford 1994). This definition takes formal and informal institutions as the outer constraints of individual action. Institutions direct and stabilize individual action by compelling certain general goals and offer more practical means (incentives and sanctions) of actualizing these goals. Institutions constitute societal scaffolding that shapes human interaction (North 2005). The challenge in institutional design and policy implementation is whether actors find these new setups sufficiently compelling and acceptable. Young (2008:21) makes the following argument: "successful governance systems must be based on a recognition of the character of the problems at hand and feature the introduction of behavioral mechanisms crafted to address these problems."

Another conception of institutions is based on the classical old institutionalism of John R. Commons and Thorstein Veblen, both of whom followed pragmatism, especially that of John Dewey and Charles S. Peirce. ${ }^{[1]}$ According to this view, institutions are not rules that are followed per se but ordered collective actions that expand, restrain, or liberate individual action (Commons 1990). This classical view resembles not only Bourdieuan sociology but also the social-ecological understanding of the structures and functionings of coevolving human-environment transactions (Emirbayer and Goldberg 2005, Hiedanpää et al. 2012, Norberg et al. 2008).

There are two schools of classical institutionalism differing on whether order is volitionally created or emerges spontaneously. Economists such as Bromley $(2006,2008)$ and Vatn (2005) and political scientists such as Pierson (2006) understand institutions as volitional collective action, manifested in policies and the way that they shape and create reasons for individual action. Hodgson (1993, 2004, 2007), on the other hand, considers habit to be the unit of selection in institutional change. Hodgson holds that institutions are emergent properties of interacting habits and that these contingent institutional patterns cause a downward pressure on individual actions and behavior. Generally, this line of reasoning also applies to the institutional and evolutionary economists of the post-Darwinian tradition (Dopfer 2007, Aldrich et al. 2008). It tends to disregard the significance of purpose and final causation.

\section{A Peircean extension}

My purpose is to stretch these theoretical orientations and focus on the analytical gap I propose. The theories make an analytic bifurcation which, in consequence, creates a black box that blurs the essential matter of institutional fit and interplay. The existence of this black box is due to their ontological and epistemological commitment to either formal or informal, volitional or spontaneous, organized or unorganized qualities when trying to understand the birth and entrenchment of institutional designs.

I will follow the same broad pragmatist approach taken by the aforementioned classical institutionalists (e.g., Hodgson 2010, Bromley 2012), but I am also sympathetic to the new institutionalist idea that institutions constitute an outer environmental scaffolding for human action and interaction, i.e., that human action and interaction are mediated by "environmental" structures and features such as ecosystems, physical infrastructures, norms, and rules (Clark 1997). I will make my case clearer by exploring the Peircean conception of habits, categories, and normative sciences more thoroughly. My purpose is to provide a nondualistic conception of institutions and apply it in the analysis of institutional fit.

\section{Habits}

According to Peirce (CP 6.101), "life has a tendency to take habits." ${ }^{[2]}$ Regularity, continuum, order, stability, and reasonableness are all manifestations of this general tendency of life. Although all habits function to fulfill a purpose of some kind, they are not fully volitional. Peirce warned us not to identify purpose with a conscious goal. To him, "a purpose is merely that form of final cause which is most familiar to our 
experience" (CP 1.211). Purposes, i.e., activities undertaken for something's sake, are nothing but operative desires, the object of which is never concrete but always general. Notice that purposes, final causes, and habits point at the potential future (Hulswit 2002). For Peirce, final causes or purposes are basically habits that habitually direct processes toward an end state.

For Peirce, there is a specific feature in this end-directedness:

\begin{abstract}
Thus we see how these principles not only lead to the establishment of habits, but to habits directed to definite ends, namely the removal of sources of irritation. Now it is precisely action according to final causes which distinguishes mental from mechanical action; and the general formula of all our desires may be taken as this: to remove a stimulus. Every man is busily working to bring to an end that state of things which now excites him to work.(CP 1.392)
\end{abstract}

The irritation (the feeling of being disturbed) motivates one to resolve the situation by adjusting action tendency, belief, and habit. The change of habit is not an easy task because it does not take only motivation and activities but involves the broader environment in which actions take place. John Dewey brings customs into the analysis of habits. Dewey (1988:43) has defined the interrelation of habit and custom eloquently: "but to a larger extent customs persist because individuals form their personal habits under conditions set by prior customs." Dewey (1988:38) continues: "Habits incorporate an environment within themselves. They are adjustments of the environment, not merely to it" [emphasis in the original].

Indeed, many of the institutional adjustments fail because of a poor fit between their habits, their customary environment, and their newly launched purposes. In essence, institutional and social change requires both habit-breaking and habittaking. Institutional fit is a matter of embodied and incorporated environmental interactions. In identifying this kind of phenomenon, Hukkinen (2012), describes it as "fit in the body."

\section{Categories}

Peirce provides theoretical and analytical tools to understand what habit-breaking and habit-taking are, and also to explain how these phenomena occur. He defines three categories to organize descriptions of the world, which will be used here to elaborate a richer conceptualization of the relationship between fit: firstness, secondness, and thirdness (Volume 5 of Collected Papers of Pierce in Pierce 1934; Potter 1967).

Firstness is a qualitative aspect of every phenomenon. We have an immediate acquaintance with firstness; it is an unanalyzed, instantaneous, immediate feeling of the sign.
"Firstness is the mode of being of that which is such as it is, positively and without reference to anything else" (CP 8.328). As Peirce articulated further, "[o]ut of the womb of indeterminacy we must say that there would have come something, by the principle of firstness, which we may call a flash" (CP 1.412). Firstness is not an actual entity but exists only in the interpreter's imagination, being hypothetical and possible (Bernstein 2010, Corlée 2009).

Secondness is an experience either of effort or resistance. According to Peirce (CP 8.330),

[t]he type of an idea of Secondness is the experience
of effort, prescinded from the idea of a purpose....
The existence of the word effort is sufficient proof
that people think they have such an idea; and that
is enough. The experience of effort cannot exist
without the experience of resistance. Effort is only
effort by the virtue of its being opposed; and no third
element enters. Note that I speak of the experience,
not of the feeling, of effort.

For Peirce, will is always set against something, reacting in the realms of relations, disturbances, and struggles.

Thirdness involves a medium or a connecting link between two things. When things or words serve a function of any kind, when the act is done for the sake of something, thirdness emerges. According to Peirce, "[t]he third is that which is what it is owing to things between which it mediates and which it brings into relation to each other" (CP 1.356). "A Third is something which brings a First into relation to a Second" [emphasis in the original] (CP 8.331) (Misak 2004).

Now we are able use Peirce's theories to understand living systems' tendency to break and take habits. Habits direct processes to an end state. Chance and possibility work toward diversity of these processes and end states. Reaction and struggle adjust habits in the face of disturbances and the admired end states. Peirce's theory of categories provides a perspective through which to study the social-ecological conditions and consequences of this general tendency to break and take habits. For our purposes, habit is thirdness, effort is secondness, and feeling is firstness. Categories are capable of combinations. Effort is an essential constituent of habit, and feeling is an essential constituent in effort and habit. In other words, emotions are constituents in (re)action, and emotions and (re)actions are constituents in habit (Potter 1967). Institutional fit is a dynamic consequence of irritation and doubt, overcoming resistance to serve a purpose.

\section{Normative sciences}

Peirce describes the task of what he calls normative sciences as differentiating "what ought to be from what ought not to be" (CP 1.186). Normative sciences can also be characterized as an analysis of "the conditions of the attainment of something of which purpose is an essential ingredient" (CP 1.575). 
Bergman (2009:56) clarifies the task: “... it seems reasonable to conceive the normativity... in terms of criticism of habits, where the categories manifest themselves on the level of the objects criticized rather than as a determinant of the sciences as such. In other words, all of the normative sciences are concerned with the criticism of conduct, albeit of different kinds."

I am the critic here. I explore the institutional conditions such that the criticism of various habits becomes possible. The Peircean normative sciences require the adoption of the ethnographic strategy. Commons (1990, see also Ramstad 1990) was well aware of this and suggested that the researcher must put him/herself in the position of the research subject and feel what the people likely felt as they were reasoning and doing. The key is to understand why and how certain actions were taken. In other words, why and how a particular action soothes the feeling, extinguishes the stimulus of irritation, and fulfills a purpose. The question is not about attitudes. It is about what actions were taken and what reasons were given for those actions. The critic must become involved in the research subject. The critic must be both an observer and a participant. The first-, second- and third-person perspectives are intertwined. The first-person perspective refers to a feeling agent, the second-person perspective to a participant in action, and the third-person perspective to the overview of the relations between the first and the second (Bohman 2001, Cooke 2006).

The primary data set is derived from interviews with the local people of southwestern Finland and the officials of the national and regional wildlife administrations. The fieldwork extends to the participant observations of everyday life in the areas that have experienced the effects of wolf presence. The interviews ranged from expansive thematic interviews (23) lasting several hours to brief mini-interviews (8) with the people spontaneously met during the fieldwork (on interviews, see Kvale 1996). Interviews were conducted between the period of 2009 and 2011. The aim of these interviews was to develop an empirical image of how the presence of the wolf affects the habits of rural communities and the administration and to enable the analysis of institutional fit and misfit (on location, see Figure 2).

\section{THE PRESENCE OF THE WOLF IN SOUTHWESTERN FINLAND}

\section{Habits of feeling / firstness}

Let me first explore the feelings aroused by a sudden appearance of the wolf. Indeed, the sudden appearance of the wolf in human settlements took communities by surprise in the Pyhäjärvi area in 2008. The predation of some 65 sheep was a shock. The event recalled the observations of the wolf, tracks and dead corpses of roe deer and other prey that had been nearly continuous throughout the year. Before that time, until 2008, the encounters had been rare and idiosyncratic. The presence of the wolf became an "excitation." On one hand, it was an aesthetic excitement, a pleasure of feeling the intensity and quality of the surrounding environment. On the other hand, it was a feeling of potential loss, threat, danger, and insecurity. In general, these feelings and expectations were mixed, and people felt concern both about and for the wolf.

The wolf intervened in the various habituated spaces. Its presence intensified the feeling that the wolf belongs in the wilderness, where its activities are irrelevant to people, and not near human settlements containing families and domestic animals. This boundary between wolves and humans and their respective territories, what one might call an "ontological agreement," was transgressed when indications of the wolf's presence began to appear within the livelihood spaces of humans. Of course, its territory, even deep in the wilderness and forest, contains human activity, hunting grounds, for example. It is this transgression into the habituated spaces that characterizes the quality of feeling provoked by the wolf's presence. The wolf belongs to the wilderness and certainly does not belong to settled human spaces.

The reappearance of the wolf activated agrarian memories. The old stories about wolves that had killed human infants were told and retold, especially by people living their rural agrarian lives on acknowledged wolf territory. These cultural memories revitalized themselves even though customs and rural daily practices are very different now. This pattern indicates that the agrarian customs (cultures) and the habits of feeling they sustain still serve particular, if not obvious, purposes. The agrarian customs and habits sustain these stories. In a similar vein, the physical structures known as "wolf holes", which refer to camouflaged holes measuring three meters wide and three meters deep for capturing wolves that come too close to the village, began to have a purpose again: protecting people and domestic animals against the wolf. The village of Tuiskula in Köyliö has displayed its four wolf holes to the public and media.

Habits are generalities, potential repertoires of acting and believing that point to the end that is achieved and admired. In general, the presence of wolves is felt as a limiting factor to the further development of individual and collective experiences in the Pyhäjärvi area. The wolf is an icon of the wilderness, the possibility of threat. In agrarian settings, signs of wolves communicate the possible harm and the loss of wellbeing. In general, the presence of wolves seems to disturb and excite strong feelings in support of the customary order.

\section{Reactions / secondness}

People act to rid themselves of irritation and doubt. In the Pyhäjärvi area, people and communities had their particular ways and reasons to react.

Human safety, especially that of children, was the first point when discussing the wolf. After the first attacks of 2008 in Köyliö, many people and communities began to quickly adjust 
their daily activities in various ways. Some decided not to walk as often in the forests. As the school year was about to begin, the community councils decided to arrange taxi rides to schools. One of the pastures in which a predation happened was situated close to summer houses. The residents were concerned about the neighboring sheep pastures because sheep attract wolves; a previous environmental amenity turned to an environmental nuisance. What is important to note, however, is that the wolf did not incite anger or hatred in this particular regard, but worry.

The security of livelihoods is another issue that arose. Farmlevel precautions rose to a new level. Sheep and goats were kept inside, and dogs were kept on a leash. The sheep farmers avoided the dangerous grazing fields and brought the sheep, goats, and cattle closer to their homes. Later that autumn, most of the farmers who had suffered losses or the threat of losses erected electric fences on certain pastures. In 2008, fencing materials could be ordered free of charge from the Regional Wildlife Agency (called Game Management District, GMD until March 2011), but the labor costs of fencing were not compensated by the government. Some of the sheep farmers disputed this policy. Moreover, due to fiscal problems, the Ministry of Agriculture and Forestry could not deliver enough fencing materials to the sheep farmers. In general, farmers were concerned for their business and livelihoods. Some were annoyed and frustrated because the governmental compensation was paid after nearly a year, a considerable lapse of time. This lag placed an additional economic burden on sheep farmers. They, along with farmers in general, found the situation disturbing.

The resistance against the instituted processes of knowledge production was a third issue. Local communities disputed the official numbers of wolves. Rumors spread that the Pyhäjärvi area, especially around Pöytyä, was surrounded by more than twenty wolves. Local hunters organized wolf censuses in Pöytyä in late 2008 and in early 2009, counting 25 and 23 wolves, respectively. The official estimates provided by the Finnish Game and Fisheries Research Institute (RKTL) indicated that Pöytyä had one territory, i.e., one wolf pack. Hunters and their organization (Finnish Hunter's Association) did not have confidence in the estimates provided by RKTL and, similarly, researchers of RKTL did not consider the hunters' counting methods to be scientifically robust. Hunters were frustrated and angry because their concern and efforts were not taken seriously.

Fourth, local people reacted to the legal and administrative rules of society. The increasing presence of the wolf brought the legal constraints to the fore. Namely, the hunters found it hard to understand why it was not possible to kill the wolves despite the fact that their presence caused concerns and exceeded a critical threshold in 2008 . The rules concerning the derogation from protecting the wolf population are strict for local hunters. Another example is even more illuminating. In one of the pastures, the sheep kept the valuable cultural landscape open, for which the sheep farmer received a specific agro-environmental subsidy. After the wolf attack, the inspector from the regional Ely-center (Centre for Economic Development, Transport and the Environment) pointed out that the pastures were undergrazed, and the sheep farmer received a several-hundred Euro penalty. The cause of the undergrazing, i.e., that the wolf killed the sheep, did not matter. Consequently, frustration and anger spread in communities. Their interests in a secure agriculture and safe livelihoods did not carry the same weight as the bureaucratic commitment to securing wolf numbers.

\section{Continuities / thirdness}

Habit relates feelings and efforts to each other. As illustrated, reactions were instantiated by the presence of the wolf. The wolf disturbed habituated spaces and customary livelihoods in the Pyhäjärvi area. Interestingly, however, the reactions were triggered by the combinations of institutional arrangements, administrative circumstances, and the wolf. Frustration and anger intensified the reactions.

Consequently, by June 2009, only a few wolf observations were made in the Pyhäjärvi area, whereas in the previous year, the observations were made continuously. There were no wolf attacks on sheep or on other domestic animals. The wolves were gone. There were no signs of the Köyliö pack that had depredated 65 sheep, and the numbers in the Pöytyä pack were greatly reduced. According to the RKTL, there were no evident ecological reasons behind the disappearance: the prey populations, roe deer and moose, were sufficiently dense, and there were no signs of lethal diseases. The only plausible explanation is that the number of the wolves had been reduced by illegal killing.

It seems that the communities of the Pyhäjärvi area solved their "wolf problem." The communities exercised social sustainability. Social sustainability of this kind is not the same breed that the EU or the Finnish national authorities wish to promote. The detailed reasons behind these local adaptive acts are still unknown, but the evidence points to respect and sympathy toward fellow humans, concern for the rights of the people over the rights of the wolf, and anger toward the authoritative agencies. The purpose of the illegal killing of the wolves was to safeguard the Pyhäjärvi communities from the potential impact of the wolves' presence and to maintain local customary order. All community members did not commit themselves to the formal wolf policy. The habits of feeling and the reactions in the face of the wolf policy indicated this. The negatively felt possibilities and negative intense emotions in reactions did not engender communities and their members to the policy. The purpose of the policy remained distant. This comes toward explaining why communities were engaged in exercising one kind of continuum over the other. This helps 
to explain why communities exercised one set of practices rather than another. It also illustrates the nature of institutional "misfit". The policy did not lead to an admired future.

\section{THE HARDSHIP OF MAKING INSTITUTIONS FIT}

The viability of the wolf population has not improved in southwestern Finland. Consequently, in 2009, the European Commission once again called for an informal discussion (the Package Meeting) on wildlife-related issues with Finnish authorities. The Commission claimed that Finland continued to have problems in the implementation and enforcement of the Habitats Directive. The wildlife administration admitted the problems and expressed its continued commitment to tighten the institutional setup concerning large carnivore protection.

\section{Weeding out the bad habits}

The Finnish government and the wildlife administration tend to understand institutions as the outer constraints of human action, which is a new institutionalist inclination (Rutherford 1994, Williamson 1996). This tendency became apparent in the fall of 2010 when the Ministry of Agriculture and Forestry enforced a legal adjustment that increased the fine for killing large carnivores. The purpose of the adjustment was to enrich the institutional scaffold with a disincentive to hunt illegally. Also, a new penal category, a serious hunting crime, was included in the criminal law. It came into force in April 2011. According to the law, the telemonitoring of suspects by the police is allowed, and a conviction leads to a prison term of four months to four years. These institutional designs build on the idea that when it comes to enforcement mechanisms, the threat of punishment is the most effective. It is expected that these newly launched institutional constraints will discourage illegal killing; the purpose is to deter the bad habits of some rural agents.

These activities may not necessarily improve the institutional fit. Namely, the weeding out of bad habits is a reactive administrative activity. We should remember that the entire emotional regime of the Finnish wolf policy is reactive. This is undoubtedly indicated by the continued struggle between the government of Finland and the Commission, the wolf enthusiasts, and the hunters, and the local hunters and wildlife science of RKTL. One Finnish wolf scientist has gone so far as to claim that the Finnish wolf conflict is insoluble, that is, there is no way that people can address the issues with the wolf or with each other when it comes to the impacts of the wolf (Bisi 2010). Indeed, according the Peircean interpretation, the problems are insoluble exactly as long as the game is played on the plateau of reactions and struggle and as long as the underlying habits of feeling and customary environments are not addressed. Until then, the solutions will build upon "the compulsion of law," i.e., reactive legislative adjustments that rely on the external constraints of human action and interaction.

\section{The currency of concern}

The government has adjusted not only the external constraints of human-wolf interactions but also the formal scaffolding of wildlife policy and management. The new Act on Wildlife Administration came into effect in March 2011. Regional Wildlife Agencies (15 in total) and Regional Wildlife Councils were established, and the previous regional Game Management Districts (GMD) (15 in total) and their board of directors were dismantled. The purpose of the institutional redesign was to establish a clearer distinction between the official wildlife management and interest politics. The Regional Wildlife Councils substitute for the previous board of directors of the GMD. The Councils comprise a maximum of 10 members: six represent the hunters and four represent other interests, such as regional land use planning, forest owners, and traffic. The councils are discursive bodies with the task of directing regional wildlife policy. The board of directors of GMD had real decision making powers, most noticeably concerning the derogation from the strict protection of the wolf. Such decisions are now made by the Finnish Wildlife Agency. The members of the GMD board of directors were local landowners and hunters. There are indications that the shift of power from the regional level to the Finnish Wildlife Agency may increase the felt impotency of rural communities, including around the Pyhäjärvi area.

By focusing primarily on the illegal killing of the wolves and by dismantling the actual power at the regional level, the government has implicitly and indirectly signaled that the local communities are, to an extent, responsible for the wolves' fate. Neither the government nor the wildlife administration has actively taken wolf-related community needs and hopes into consideration. In other words, the administration has a habit of ignoring the reasons behind the communities' reactions or negative feelings. This habit has become apparent in how reluctant the administration has been to alleviate the economic and emotional burdens engendered by the wolves' presence. The regulatory apparatus that the government has erected has left the sources of frustration and anger intact. Its noninterventionist policy has an accidental tendency to increase the populace's feelings of insecurity, helplessness, and anger. The government has not actively designed institutions for positive order and growth. The government itself exercises discipline and control, which is, again, a reactive characteristic of governance.

\section{Making rules, not love}

The government's focus has been habit-breaking. The government has done little in terms of habit-taking among rural communities that would help them to adapt to the wolves' presence. The government has not designed institutions to enshrine habits of moral and intellectual growth. The government's normative effort, which involves the ongoing criticism of local habits, is not expansive but constraining. It considers neither the underlying emotional regime nor the 
critical conditions of habit formation. The administration has, of course, admitted that fear is real and that it has material manifestations and practical implications. However, community members have continued to exercise their private negative freedoms and have spontaneously, without active governmental assistance, adjusted their community-based customs and habits in particular ways. The viability of the wolf population has not been on their list of priorities.

Habits change when environment-human interactions change. It is not only a matter of fixing outer constraints. The government's participation in the process of habit-taking could facilitate a move towards what Peirce called concrete reasonableness (Ward 2001). This term means that the collaboration and collateral learning potentially facilitate a gradual shift in what is admired in given environmental settings and how the agents react to the next disturbance. The shared experiences lead to gradual changes concerning what people consider an attainable end. Concrete reasonableness is characterized by epistemic commitment to collaborate as a community to find, redescribe, and create admired ends, appropriate actions, and warranted epistemic practices (Ward 2001, Talisse 2010). Concrete reasonableness is a process of adjusted habit-taking. Institutional fit is not a matter of correctly establishing the external constraints or constructing the negative apparatuses. Institutional fit is about creating, designing, and erecting the positive, enabling environmental apparatuses. In the Pyhäjärvi area, the interested individuals and groups have already taken initiatives for more collaboration. However, as long as the government, the wildlife administration, or the research institute RKTL are not actively taking part in these efforts, wolf policy is hardly becoming any fitter or more reasonable. It takes shared feelings and visions about the admired to grow habits. This indeed will continue to challenge Finnish wolf policy.

\section{CONCLUDING REMARKS}

Reflecting on the Pyhäjärvi area, are the initiated policy measures the most appropriate and the most effective in breaking and taking new habits that allow communities to coexist with the wolves? Do the recent policy measures resolve the concerns, reestablish feelings of security, or help community members to live with the presence of the wolf? No, they probably do not. Apparently, these communities, which have been disturbed by the wolf and the unresponsiveness of the wildlife administration, continue to admire certain purposes and encourage certain codes of conduct that are not the most honorable or law-abiding, but which are expected to safeguard the continuity of rural life. The government may initiate changes and may provide enabling institutions and facilitate the micro-mechanism of adaptation. As this classical institutionalist analysis has shown, as long as those instruments are reactive and compulsive and not collaborative engagement of whole epistemic community in habit-taking, they will the most likely fail (on epistemic communities, see Haas 1992). In collaboration, customs, habits, and the ensuing emotional regimes may slowly begin to change. Institutions, the various forms of ordered collective actions, may begin to better fit together in the habituated social-ecological space in which the people, communities, and the wolf live. It will not be an exact fit because no such thing exists. However, if the government ensures that the wildlife policy enables concrete collaboration and collateral learning, fit may become doable, possible and reasonable, for the time being.

Responses to this article can be read online at: http://www.ecologyandsociety.org/issues/responses. php/5302

\section{Acknowledgments:}

I would like to thank Daniel Bromley, Janne Hukkinen, Sauli Härkönen, Jani Pellikka, and the Special Feature editor Kate Farrell for the valuable comments on the earlier version of the manuscript. I also thank the anonymous reviewers and the Academy of Finland (253750).

\section{LITERATURE CITED}

Aldrich, H. E., G. M. Hodgson, D. L. Hull, T. Knudsen, J. Mokyr, and V. J. Vanberg. 2008. In defence of generalized Darwinism. Journal of Evolutionary Economics 18:577-96.

Bergman, M. 2009. Peirce's philosophy of communication. Continuum, London, UK.

Bernstein, R. 2010. The pragmatic turn. Polity Press, London, UK.

Bisi, J. 2010. Suomalaisen susipolitiikan anatomia [The anatomy of Finnish wolf policy]. Acta Universitatis Ouluensis Scientiae Rerum Naturalium A 552. University of Oulu, Oulu, Finland.

Bisi, J., and S. Kurki. 2008. The wolf debate in Finland: expectations and objectives for the management of the wolf population at regional and national level. Publications 12. Helsinki University, Ruralia Institute, Seinäjoki, Finland.

Bohman, J. 2001. Participants, observers and critics: practical knowledge, social perspectives, and critical pluralism. Pages 87-113 in L. Rehg, and J. Bohman, editors. Pluralism and the pragmatic turn. MIT Press, Boston, Massachusetts, USA.

Bromley, D. W. 2006. Sufficient reason: volitional pragmatism and the meaning of economic institutions. Princeton University Press, Princeton, USA. 
Bromley, D. 2008. Volitional pragmatism. Ecological Economics 68(1-2):1-13. http://dx.doi.org/10.1016/j. ecolecon.2008.08.012

Bromley, D. W. 2012. Environmental governance as stochastic belief updating: crafting rules to live by. Ecology and Society 17(3):14. [online] URL: http://dx.doi. org/10.5751/ES-04774-170314

Clark, A. 1997. Economic reason: the interplay of individual learning and external structure. Pages 269-290 in J. N. Drobak, and J. V. C. Nye, editors. The frontiers of the new institutional economics. Academic Press, San Diego, California, USA.

Commons, J. R. 1990. Institutional economics: its place in political economy. Transaction, London, UK.

Cooke, E. F. 2006. Peirce's pragmatic theory of inquiry: fallibilism and indeterminacy. Continuum, London, UK.

Corlée, L. 2009. A sketch of Peirce's firstness and its significance to art. Sign Systems Studies 37:205-269.

Dewey, J. 1988. Human nature and conduct. The middle works of John Dewey. Volume 14. Southern Illinois University Press, Carbondale and Edwardsville, Illinois, USA.

Dopfer, K., editor. 2007. The evolutionary foundations of economics. Cambridge University Press, Cambridge, UK.

Emirbayer, M., and C. A. Goldberg. 2005. Pragmatism, Bourdieu and collective emotions in contentious politics. Theory and Society 34:469-518. http://dx.doi.org/10.1007/ s11186-005-1619-X

European Court of Justice. 2007. Judgment of the Court (Second Chamber) of 14 June 2007. Commission of the European Communities v Republic of Finland. Failure of a member state to fulfil its obligations - Directive 92/43/EEC conservation of natural habitats - wild fauna and flora - Wolf hunting. Case C-342/05. [online] URL: http://curia.europa.eu/ juris/liste.jsf?language $=$ en $\&$ num $=\mathrm{C}-342 / 05$

Haas, P. M. 1992. Introduction: epistemic communities and international policy coordination. International Organization 46:1-35. http://dx.doi.org/10.1017/S0020818300001442

Hiedanpää, J., and D. W. Bromley. 2011. The harmonization game: reasons and rules in European biodiversity policy. Environmental Policy and Governance 21:99-111. http://dx. doi.org/10.1002/eet.561

Hiedanpää, J., and D. W. Bromley. 2012. Contestations over biodiversity protection. Environmental Values 3:357-378. http://dx.doi.org/10.3197/096327112X13400390126091

Hiedanpää, J., A. Jokinen, and P. Jokinen. 2012. Making sense of the social: human-nonhuman constellations and the wicked road to sustainability. Sustainability: Science, Practice, \& Policy 7:15-24.
Hodgson, G. M. 1993. Economics and evolution: bringing life back into economics. Polity Press, Cambridge, UK.

Hodgson, G. M. 2004. The evolution of institutional economics: agency, structure and Darwinism in American institutionalism. Routledge, London, UK. http://dx.doi. org/10.4324/9780203300350

Hodgson, G. M. 2007. Economics in the shadow of Darwin and Marx: essays in institutional and evolutionary themes. Edward Elgar, London, UK.

Hodgson, G. M. 2010. Choice, habit and evolution. Journal of Evolutionary Economics 20:1-18. http://dx.doi.org/10.1007/ s00191-009-0134-Z

Hukkinen. J. 2012. Fit in the body: matching embodied cognition with social-ecological systems. Ecology and Society 17(4):30. http://dx.doi.org/10.5751/ES-05241-170430

Hulswit, M. 2002. From cause to causation: a Peircean perspective. Philosophical Studies Series. Volume 90. Kluwer Academic Publishers, Dordrecht, Netherlands. http://dx.doi. org/10.1007/978-94-010-0297-4

Kojola, I., P. Helle, and S. Heikkinen. 2011. Susikannan viimeaikaiset muutokset Suomessa eri aineistojen valossa. Suomen Riista 57:55-62.

Kvale, S. 1996. InterViews. Sage, London, UK.

Management plan for the wolf population in Finland. 2005. Ministry of Agriculture and Forestry, Helsinki, Finland. [online] URL: http://wwwb.mmm.fi/julkaisut/julkaisusarja/2005/ MMMjulkaisu2005_11b.pdf

Mirowski, P. 1988. Against mechanism: protecting economics from science. Rowman \& Littlefield, Lanham, Maryland, USA.

Misak, C. 2004. Charles Sanders Peirce (1839-1914). Pages 1-26 in C. Misak, editor. The Cambridge companion to Peirce. Cambridge University Press, Cambridge, Boston, USA. http:// dx.doi.org/10.1017/CCOL0521570069.001

Norberg, J., J. Wilson, B. Walker, and E. Ostrom. 2008. Diversity and resilience of social-ecological systems. Pages 46-79 in J. Norberg, and G. C. Cumming, editors. Complexity theory for a sustainable future. Columbia University Press, New York, USA.

North, D. C. 2005. Understanding the process of economic change. Princeton University Press, Princeton, New Jersey, USA.

Norton, B. G. 1996. Integration or reduction: two approaches to environmental valuation. Pages 105-138 in A. Light, and E. Katz, editors. Environmental Pragmatism. Routledge, London, UK. 
Norton, B. G. 2005. Sustainability: the philosophy of adaptive ecosystem management. Chicago University Press, Chicago, Illinois, USA.

Peirce, C. S. 1934. Collected papers of Charles S. Peirce, 8 volumes. C. Hartshorne, and P. Weiss (volumes 1-6), and A. Burks (volumes 7-8). Harvard University Press, Cambridge, Massachusetts, USA.

Pierson, P. 2006. Public policies as institutions. Pages 114134 in I. Shapiro, S. Skowronek, and D. Galvin, editors. Rethinking institutions: the art of the state. New York University Press, New York, USA.

Potter, V. G. 1967. Charles S. Peirce on norms \& ideals. University of Massachusetts Press, Boston, Massachusetts, USA.

Ramstad, Y. 1990. The institutionalism of John R. Commons: theoretical foundations of volitional economics. Pages 53-104 in $\mathrm{W}$. Samuels, editor. Research in the history of economic thought and methodology. JAI Press, Boston, Massachusetts, USA.

Rutherford, M. 1994. Institutions in economics: the old and the new institutionalism. Cambridge University Press, Cambridge, Boston, Massachusetts, USA. http://dx.doi. org/10.1017/CBO9780511625879

Talisse, R. B. 2010. Peirce and pragmatist democratic theory. Pages 105-116 in M. Bergman, S. Paavola, A.-V. Pietarinen, and $\mathrm{H}$. Rydenfelt, editors. Ideas in action: proceedings of the Applying Peirce Conference. Nordic studies in pragmatism 1. Nordic Pragmatism Network, Helsinki, Finland.

Vatn, A. 2005. Institutions and the environment. Edward Elgar, London, UK.

Vatn, A., and P. Vedeld. 2012. Fit, interplay, and scale: a diagnosis. Ecology and Society 17(4):12. http://dx.doi. org/10.5751/ES-05022-170412

Ward, R. 2001. Peirce and politics. Philosophy and social criticism 27:67-90. http://dx.doi.org/10.1177/019145370102700304

Williamson, O. 1996. The mechanisms of governance. Oxford University Press, Oxford, UK.

Young, O. R. 2002. The institutional dimensions of environmental change: fit, interplay, and scale. MIT Press, Boston, Massachusetts, USA.

Young, O. R. 2008. The architecture of global environmental governance: bringing science to bear on policy. Global Environmental Politics 8:14-32. http://dx.doi.org/10.1162/ glep.2008.8.1.14

${ }^{[1]}$ John R. Commons (1862-1945) is considered one of the founding fathers, together with Thorstein Veblen (1857-1929) and Wesley Mitchell (1874-1948), of institutional economics. Their debt to pragmatism is well known (Mirowski 1988:106-133; Ramstad 1990; Hodgson 2004). In his magnum opus, Commons devotes an extensive section to Peirce. To Commons, Peirce's philosophy of science and the role of habits in social and economic life are obvious (see Commons 1990, 102, 140-157.) Already, Bromley (2006), Hodgson (1993; 2004), and Ramstad (1990) have worked on combining classical institutionalism with Peirce's philosophy of science; Norton $(1996 ; 2005)$ has worked to combine environmental pragmatism with Peirce's philosophy of science; and Hiedanpää and Bromley (2012) have worked on institutional change from the viewpoint of Peirce's theory of signs.

${ }^{[2]}$ Peirce's Collective Papers are conventionally cited by volume and paragraph number. 